\title{
GENETIC VARIABILITY AND CORRELATION STUDIES OF MULBERRY (MORUS ALBA L.) GENOTYPES IN BANGLADESH
}

\author{
Md Serajur Rahman ${ }^{1}$ and SM Shahinul ISLaM* \\ Institute of Biological Sciences, University of Rajshahi, Rajshahi-6205, Bangladesh \\ Keywords: Correlation, Genetic advance, Heritability, Mulberry, Variability
}

\begin{abstract}
Morphological, phenotypical and yield attributing characteristics of 20 mulberry genotypes were evaluated. Genotypic and phenotypic variations, heritability, genetic advance and correlation co-efficient were also estimated. It was found that the phenotypic co-efficient of variation (PCV) was higher (97.68\%) than genotypic co-efficient of variation (GCV, 96.99\%). The broad sense heritability for these traits ranged from 98.60 (AL) to 4.69 (LLS). High heritability coupled with high genetic advance was recorded for the characters apex length (AL), leaf length (LL), leaf width (LW), leaf petiole ratio (LPR) and petiole length (PL) suggesting the higher genetic control over these traits. Significant positive correlations to leaf yield/plant were observed for the characters, namely total shoot weight (0.817), longest shoot length (0.600), total branch height (0.596) and leaves fresh weight/10 leaves (0.425). Leaf yield showed significantly positive phenotypic and genotypic correlations with all other growth traits (viz., total shoot weight 0.817 , length of longest shoot 0.600 , total branch height 0.596 and leaves fresh weight/10 leaves 0.425 ) except total branch number, nodes per meter, leaf width and petiole length. High genetic advance as percentage of mean coupled with heritability was observed on AL, LL, LW, LPR, PL and 10 fresh leaves weight suggesting the prevalence of additive gene action with low environmental influence for the determination of these characters and could be effective in phenotypic selection. Analysis of variances (ANOVA) for characters such as AL, LL, LW, LPR and PL showed significant variations among the genotypes. Since mulberry is mainly cultivated for leaf yield, genotypes having higher AL, LL, LW and LPR and PL must be given importance during parent selection to evolve high yielding varieties across different seasons in mulberry.
\end{abstract}

Mulberry (Morus spp.) is a perennial tree cultivated as a seasonal crop by regular pruning and training for sustained supply of foliage to rear the silkworm Bombyx mori L., which feeds only on mulberry leaves. The plants are cultivated under both tropical and temperate climatic conditions of different regions in Bangladesh. As leaf productivity is one of the principal factors that decide the sustainability and profitability of sericulture, good quality mulberry leaf increases the cocoon productivity and quality of silk (Ashiru 2002, Doss et al. 2012). It is grown as small bushes and $60 \%$ of cost involved in total production of silkworm cocoon production goes to mulberry cultivation only (Das and Swami 1965). Development of high yielding superior cultivars is a major challenge and goals for the breeders. Variability assessment among the germplasms and creation of variability are two major components for any breeding programme to be successful (Murthy et al. 2010). They also reported quantitative characters on leaf yield that associated with many contributing traits. The extent and magnitude of genetic variability in the mulberry germplasm help in the crop improvement through conventional breeding. Genetic variability is the pre-requisite for initiation of any crop improvement programme including mulberry and selection acts upon the variability which is present in the genotypes (Saini et al. 2018). Prior knowledge of genetics on yield contributing traits is very essential to formulate a

*Author for corresponding: <shahinul68@gmail.com>. ${ }^{1}$ Bangladesh Sericulture Development Board, Baliapukur, Rajshahi-6207, Bangladesh. 
breeding strategy of mulberry. Under this circumstances the present work was undertaken to estimate the extent of genotypic and phenotypic variation, heritability, genetic advance and inter-relationship of different yield and yield contributing traits among the selected genotypes of mulberry.

Twenty mulberry genotypes viz., BSRM5, BSRM16, BSRM18, BSRM19, BSRM20, BSRM24, BSRM34, BSRM39, BSRM40, BSRM45, BSRM50, BSRM54, BSRM55, BSRM56, BSRM58, BSRM59, BSRM63, BSRM64, BSRM65 and BSRM66 were collected and maintained in the Germplasm bank of Bangladesh Sericulture Research and Training Institute (BSRTI), Rajshahi, Bangladesh. Data were recorded and analyzed during four cropping seasons for final yield trial (FYT) in 2017 - 2018. The plantation was made with 12 plants in each replication with $90 \times 90 \mathrm{~cm}$ spacing under randomized block design (RBD) with three replications. Recommended cultural practices about 4-crops schedule were followed by standard methods of BSRTI (Quader et al. 1992). Irrigation was provided as and when required. Data from the middle 5 plants were recorded on various growth and yield attributing traits such as total branch number (TBN), total branch height (TBH), nodes/meter (N/M), internodal distance (IND), length of longest shoot (LLS), leaf length (LL), leaf width (LW), petiole length (PL), apex length (AL), 10 fresh leaves weight (FLW), leaf petiole ratio (LPR), total shoot weight (TSW), leaf yield (LY) and moisture content (MC). Total branch height (TBH) is the sum up on number of branch on a plant. Five plants were measured in $\mathrm{cm}$ for each genotype and was made an average. For FLW 10 leaves were harvested at random and weighed, five samples of 10 leaves of each genotype were taken. To measure the leaf, petiole ratio (LPR) leaf and petiole length were recorded in $\mathrm{cm}$ in five plants per genotype and the leaf petiole ratio was calculated on the basis of average lengths. Data were analyzed by one way ANOVA followed by DMRT using a commercially available statistics software package (SPSS ${ }^{\circledR}$ for Windows, V. 22.0, Chicago). Data were statistically analyzed for genotypic and phenotypic co-efficient of variance (GCV and PCV), broad sense heritability and genetic advance (GA) following the standard methods of Burton and Devane (1953) and Hanson et al. (1956). Genotypic, phenotypic and environmental correlations between yield and yield attributing characters were also estimated by Weber and Moorthy (1952).

Experimental findings based on the data pooled over four seasons are presented in Table 1. All the seasons selected for evaluation had significant effect on the expression of all the traits. The highest (14.42) branch per plant was recorded in BSRM56 and lowest (8.10) in BSRM59. The total branch height per plant was highest $(1810.20 \mathrm{~cm})$ in BSRM19 and lowest $(929.00 \mathrm{~cm})$ in BSRM54. Nodes per meter were recorded highest (33.55) in BSRM20 and lowest (22.90) in BSRM55. Internodal distance was recorded highest (4.63) in BSRM55 and lowest (3.03) in BSRM20. Length of longest shoot was highest $(178.00 \mathrm{~cm})$ in BSRM5 and lowest (107.85) in BSRM20. Leaf length was recorded highest $(20.44 \mathrm{~cm})$ in BSRM20 and lowest $(9.04 \mathrm{~cm})$ in BSRM5. Leaf width was observed highest $(17.34 \mathrm{~cm})$ in BSRM20 and lowest $(7.05 \mathrm{~cm})$ in BSRM58. Leaf petiole length was found highest $(4.00 \mathrm{~cm})$ in BSRM20 and lowest $(2.60 \mathrm{~cm})$ in BSRM50. Apex length was found highest $(6.75 \mathrm{~cm})$ in BSRM20 and lowest $(0.70 \mathrm{~cm})$ in BSRM58 (Table1). Ten fresh leaves weight per plant was observed highest (49.00 g) in BSRM64 and lowest $(20.75 \mathrm{~g})$ in BSRM58. Total shoot weight was observed highest (748.15 g) in BSRM5 and lowest $(362.70 \mathrm{~g})$ in BSRM20. Leaf petiole ratio by length was recorded highest $(6.37 \mathrm{~cm})$ in BSRM63 and lowest $(3.47 \mathrm{~cm})$ in BSRM39. Leaf yield per plant was recorded highest $(1019.00 \mathrm{~g})$ in BSRM 64 and lowest $(602.58 \mathrm{~g})$ in BSRM54. Moisture content of leaf was recorded highest (77.80\%) in BSRM24, BSRM39, BSRM64 and lowest (73.50\%) in BSRM56.

In accordance with the variability, maximum phenotypic variance was observed in TBH (149741.44) followed by LY (37841.82) and TSW (34136.77) indicating the maximum influence of environment on thesecharacters and comparatively minimum range of variability and phenotypic 


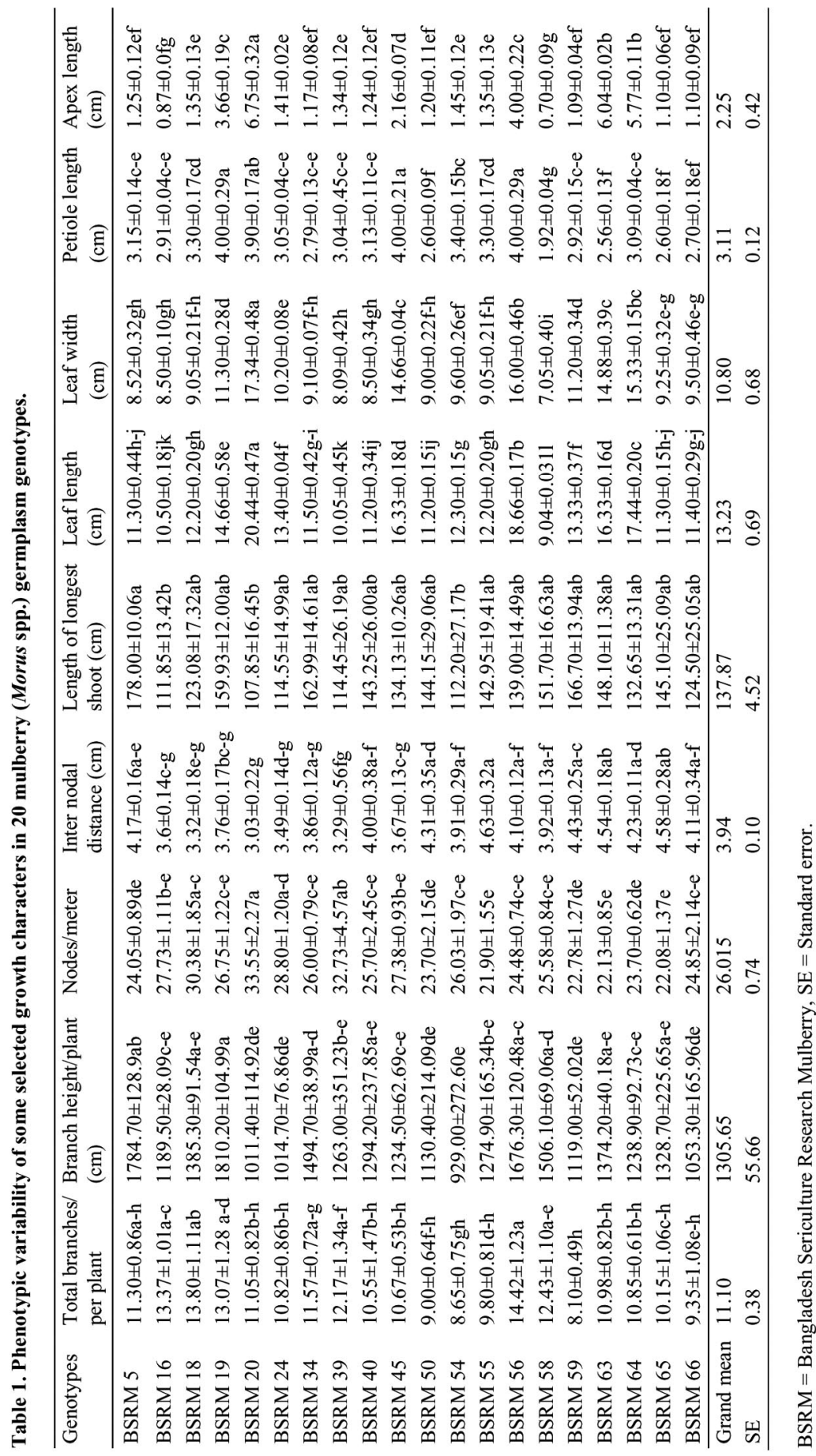


variance was recorded in IND (0.45). However, the least phenotypic variance was observed in IND followed by PL, LPR, MC and AL indicated the strong genetic control on the expression of these characters. Significant genotypic co-efficient of variance (GCV) and phenotypic co-efficient of variance $(\mathrm{PCV})$ were observed for yield and different yield attributing characters. The PCV was higher than the GCV for all the characters and it ranged between 2.31 (MC) and 97.68 (AL). The maximum GCV was recorded in AL. The phenotypic coefficient of variation was higher than the genotypic coefficient of variation for all the characters and was highest in apex length (97.68), leaf width (33.01), 10 fresh leaves weight (32.50), total branch height (29.64) and was least in MC (2.31). Similar type of results was also reported by Mallikarjunappa et al. (2008), Roy et al. (2015) and Suresh et al. (2017).

Table 2. Phenotypic variability of some selected yield characters in 20 mulberry (Morus spp.) germplasm genotypes.

\begin{tabular}{|c|c|c|c|c|c|}
\hline Genotypes & $\begin{array}{l}10 \text { fresh leaves } \\
\text { wt./plant }(\mathrm{g})\end{array}$ & $\begin{array}{l}\text { Total shoot wt. } \\
(\mathrm{g})\end{array}$ & $\begin{array}{l}\text { Leaf-petiole } \\
\text { ratio by length } \\
(\mathrm{cm})\end{array}$ & $\begin{array}{l}\text { Leaf yield/ } \\
\text { plant }(\mathrm{g})\end{array}$ & $\begin{array}{l}\text { Moisture } \\
\text { content }(\%)\end{array}$ \\
\hline BSRM 5 & $26.50 \pm 2.10 \mathrm{e}-\mathrm{h}$ & $748.15 \pm 113.35 \mathrm{a}$ & $3.61 \pm 0.23 f g$ & $733.60 \pm 93.09 \mathrm{a}$ & $75.50 \pm 0.89 b-f$ \\
\hline BSRM 16 & $36.13 \pm 2.31 b-\mathrm{e}$ & $562.53 \pm 112.22 \mathrm{a}$ & $3.61 \pm 0.05 f g$ & $883.54 \pm 107.45 a$ & $77.10 \pm 0.19 \mathrm{ab}$ \\
\hline BSRM 18 & $22.88 \pm 1.5 h$ & $511.03 \pm 83.83 \mathrm{a}$ & $3.72 \pm 0.14 \mathrm{e}-\mathrm{g}$ & $624.48 \pm 163.48 a$ & $76.65 \pm 0.78 \mathrm{a}-\mathrm{d}$ \\
\hline BSRM 19 & $24.75 \pm 1.44 \mathrm{f}-\mathrm{h}$ & $661.98 \pm 51.77 \mathrm{a}$ & $3.67 \pm 0.19 \mathrm{e}-\mathrm{g}$ & $772.63 \pm 129.25 a$ & $74.50 \pm 0.15 f g$ \\
\hline BSRM 20 & $28.00 \pm 4.63 \mathrm{e}-\mathrm{h}$ & $362.70 \pm 94.57 \mathrm{a}$ & $5.26 \pm 0.12 b c$ & $602.58 \pm 116.23 a$ & $75.50 \pm 0.21 b-f$ \\
\hline BSRM 24 & $37.00 \pm 5.02 \mathrm{~b}-\mathrm{e}$ & $437.15 \pm 74.79 \mathrm{a}$ & $4.40 \pm 0.06 \mathrm{~d}$ & $814.90 \pm 128.34 a$ & $77.80 \pm 0.09 a$ \\
\hline BSRM 34 & $30.50 \pm 1.04 \mathrm{~d}-\mathrm{h}$ & $685.93 \pm 93.02 \mathrm{a}$ & $4.12 \pm 0.04 \mathrm{~d}-\mathrm{g}$ & $848.53 \pm 152.73 a$ & $75.20 \pm 0.09 \mathrm{~b}-\mathrm{g}$ \\
\hline BSRM 39 & $24.50 \pm 4.66 \mathrm{gh}$ & $546.55 \pm 184.97 a$ & $3.47 \pm 0.38 \mathrm{~g}$ & $657.13 \pm 248.36 a$ & $77.80 \pm 0.31 \mathrm{a}$ \\
\hline BSRM 40 & $28.13 \pm 5.72 \mathrm{e}-\mathrm{h}$ & $570.85 \pm 191.16 a$ & $3.58 \pm 0.14 \mathrm{fg}$ & $780.73 \pm 246.36 a$ & $76.80 \pm 0.52 \mathrm{a}-\mathrm{c}$ \\
\hline BSRM 45 & $34.25 \pm 2.29 \mathrm{c}-\mathrm{g}$ & $538.95 \pm 52.66 \mathrm{a}$ & $4.08 \pm 0.21 \mathrm{~d}-\mathrm{g}$ & $845.30 \pm 80.07 \mathrm{a}$ & $74.70 \pm 0.09 \mathrm{e}-\mathrm{g}$ \\
\hline BSRM 50 & $39.53 \pm 3.17 a-d$ & $498.45 \pm 169.22 \mathrm{a}$ & $4.31 \pm 0.13 \mathrm{de}$ & $763.65 \pm 194.75 a$ & $74.80 \pm 0.28 \mathrm{~d}-\mathrm{g}$ \\
\hline BSRM 54 & $40.25 \pm 6.21 \mathrm{a}-\mathrm{d}$ & $520.95 \pm 200.91 \mathrm{a}$ & $3.64 \pm 0.17 \mathrm{fg}$ & $659.30 \pm 270.40 a$ & $74.90 \pm 0.07 \mathrm{c}-\mathrm{g}$ \\
\hline BSRM 55 & $35.75 \pm 3.10 b-f$ & $561.78 \pm 157.92 \mathrm{a}$ & $3.72 \pm 0.14 \mathrm{e}-\mathrm{g}$ & $698.70 \pm 181.38 \mathrm{a}$ & $76.65 \pm 0.78 \mathrm{a}-\mathrm{d}$ \\
\hline BSRM 56 & $37.38 \pm 2.91 \mathrm{~b}-\mathrm{e}$ & $668.90 \pm 118.13 a$ & $4.74 \pm 0.34 \mathrm{~cd}$ & $922.50 \pm 139.59 a$ & $73.50 \pm 0.29 g$ \\
\hline BSRM 58 & $20.75 \pm 0.85 h$ & $594.03 \pm 75.05 \mathrm{a}$ & $4.72 \pm 0.12 \mathrm{~cd}$ & $965.85 \pm 140.30 \mathrm{a}$ & $74.50 \pm 0.20 \mathrm{fg}$ \\
\hline BSRM 59 & $44.95 \pm 2.60 \mathrm{a}-\mathrm{c}$ & $554.08 \pm 65.68 \mathrm{a}$ & $4.57 \pm 0.17 d$ & $761.50 \pm 119.82 a$ & $76.10 \pm 0.13 a-f$ \\
\hline BSRM 63 & $47.00 \pm 1.86 \mathrm{ab}$ & $613.53 \pm 79.62 \mathrm{a}$ & $6.37 \pm 0.35 a$ & $998.34 \pm 114.56 a$ & $77.60 \pm 0.29 a$ \\
\hline BSRM 64 & $49.00 \pm 2.27 \mathrm{a}$ & $590.78 \pm 104.09 a$ & $5.64 \pm 0.10 b$ & $1019 \pm 134.57 \mathrm{a}$ & $77.80 \pm 0.4 a$ \\
\hline BSRM 65 & $41.75 \pm 2.69 a-d$ & $660.98 \pm 182.73 a$ & $4.41 \pm 0.31 d$ & $827.20 \pm 223.57 a$ & $76.00 \pm 1.83 \mathrm{a}-\mathrm{f}$ \\
\hline BSRM 66 & $42.75 \pm 4.75 \mathrm{a}-\mathrm{c}$ & $732.95 \pm 194.50 \mathrm{a}$ & $4.26 \pm 0.18 \mathrm{~d}-\mathrm{f}$ & $853.25 \pm 222.28 \mathrm{a}$ & $76.50 \pm 0.46 \mathrm{a}-\mathrm{e}$ \\
\hline Grand mean & 34.58 & 581.11 & 4.295 & 801.63 & 75.99 \\
\hline SE & 1.89 & 21.29 & 0.17 & 26.83 & 0.29 \\
\hline
\end{tabular}

The selection efficiency was higher when the parameters had higher heritability. Estimation of genotypic coefficient of variation and heritability gives the best information for getting desirable characters through parental selection and hybridization (Burton and Devane 1953). Difference between PCV and GCV was minimum in all characters except that in length of longest shoot, total branch height, total shoots weight suggesting higher influence of environmental factors on these characters. Heritability $\left(h^{2}\right)$ was highest in apex length (98.60) followed by in leaf length (97.25), leaf width (96.99) leaf petiole ratio by length (81.62), petiole length (72.30), 10 fresh leaves weight (62.91) and leaf moisture content (57.60). Such high level of heritability may be due to the excessive additive gene effect. 


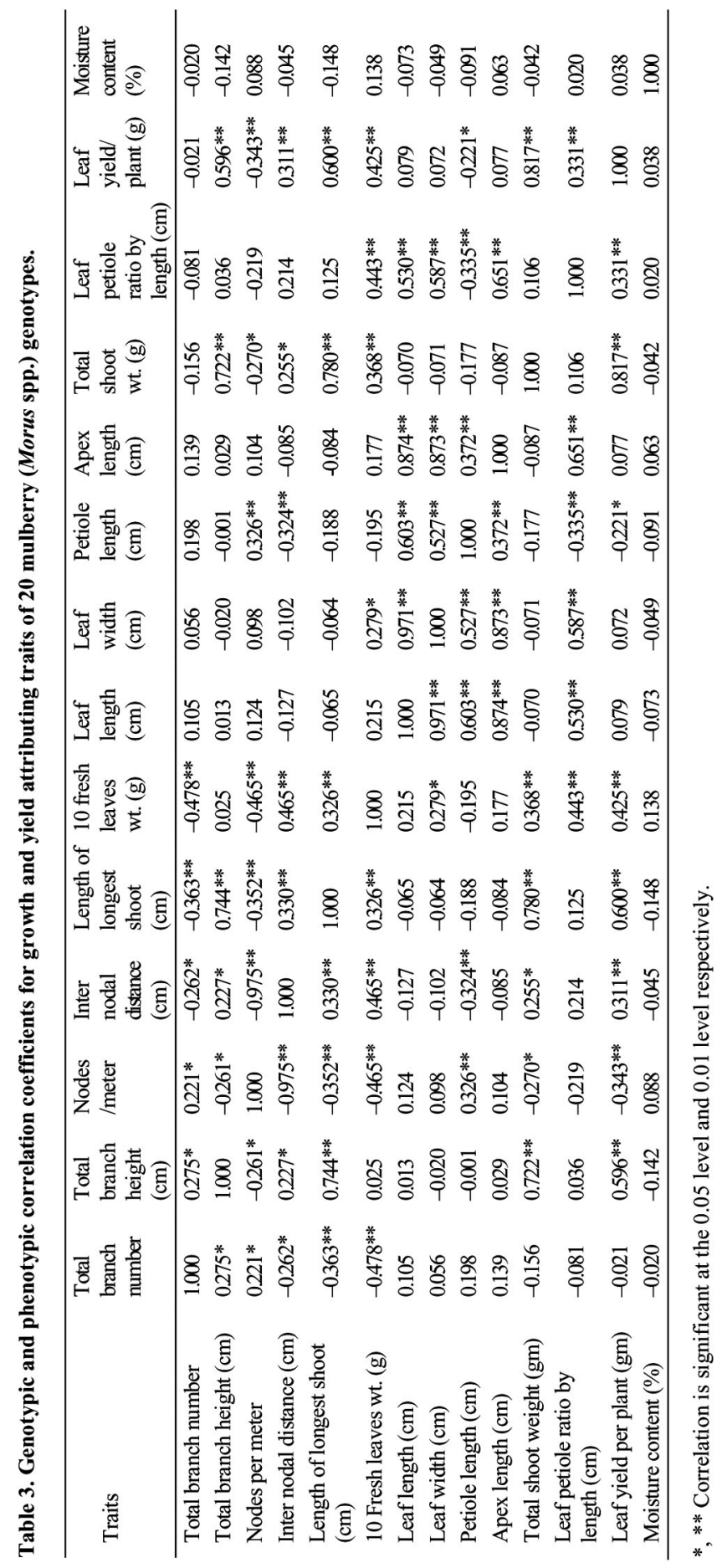


The heritability estimates along with genetic gain is more useful than heritability alone in predicting the resultant effects of selection (Johnson et al. 1955). Earlier studies in mulberry also stated that quantitative traits with high $\mathrm{h}^{2}$ and GA responded better than others to simple phenotypic selection as they contribute to additive gene action, which will aid in effective selection for obtaining genetic improvement of polygenetic traits in mulberry (Masilamani et al. 2000). In the present study also, high GA, as \% of mean, coupled with high heritability was observed for the characters viz., apex length $\left(h^{2}=98.60\right.$; GA\% $\left.=198.68\right)$; leaf width $\left(h^{2}=96.99\right.$; GA\% $=66.05)$; leaf length $\left(\mathrm{h}^{2}=97.25 ; \mathrm{GA} \%=54.46\right) ; 10$ fresh leaves weight $\left(\mathrm{h}^{2}=62.91 ; \mathrm{GA} \%\right.$ $=42.18)$; leaf petiole ratio $\left(\mathrm{h}^{2}=81.62 ; \mathrm{GA} \%=36.96\right)$ and petiole length $\left(\mathrm{h}^{2}=72.30 ; \mathrm{GA} \%=\right.$ 33.65).

High genetic advance as percentage of mean coupled with heritability was observed in the characters, namely apex length, leaf length, leaf width, leaf petiole ratio by length, petiole length and 10 fresh leaves weight. This suggests the prevalence of additive gene action with low environmental influence for the determination of these characters and could be effective in phenotypic selection. Moderate genetic advance as percentage of mean coupled with high heritability noticed for the characters total branch number per plant, nodes per meter, internodal distance and leaf yield per plant indicated the presence of intra and inter allelic interactions in the expression of these characters. These result agreed well with the observation made by Goel et al. (1998), Tikader et al. (2004), Banerjee et al. (2007), Mallikarjunappa et al. (2008), Tikader and Kamble (2008), Doss et al. (2012), Biradar et al. (2015) and Suresh et al. (2017). Previously similar findings of high $\mathrm{h}^{2}$ and GA\% were reported for the characters viz., leaf yield, weight of 10 fresh leaves and SLA among 9 different species of mulberry (Doss et al. 2006). A high $\mathrm{h}^{2}$ coupled with high GA\% for the characters viz., leaf area and weight of 100 leaves (fresh) were observed among 77 mulberry germplasm accessions (Rahman et al. 2006).

Correlation among the 14 growths and yield attributing characters revealed substantial differences between phenotypic and genotypic correlations (Table 3). Predominantly, the magnitude of genotypic correlations was higher than their corresponding phenotypic correlations. Leaf yield had significant positive correlations with all the yield attributing characters except N/M and PL, which showed significant negative correlations. Petiole length had significant negative correlations with all important yield attributing characters with high heritability viz., IND, LPR, LY. Therefore, the yield attributes which are genetically controlled having high heritability and GA and also having significant positive association with leaf yield viz., TSW, LLS, TBH, LW and LPR and significant negative correlation of N/M and PL are worth considering for parental selection aiming developing high yielding mulberry varieties. Similar results obtained in case of leaf size and shoot lengths were highly correlated with leaf yield that agreed most of the earlier observations (Tikader and Kamble 2008 and 2009, Vijayan et al. 1997).

\section{Acknowledgements}

Authors are thankful to the Ministry of Science and Technology, Government of the People's Republic of Bangladesh for granting scholarship of this study to Serajur Rahman. Thanks also to the Institute of Biological Sciences, University of Rajshahi and Bangladesh Sericulture Research \& Training Institute (BSRTI) for providing research support and related facilities.

\section{References}

Ashiru MO 2002. The effect of mulberry varieties on the performance of Chul Thai-5 silkworm race. Discovery and Innovation 14: 77-83.

Banerjee R, Roychowdhuri S, Sau H, Das BK, Pannalal G and Saratchandra B 2007. Genetic diversity and interrelationship among mulberry genotypes. J. Genet. Genomes 34(8): 691-697. 
Biradar J, Chikkalingaiah, Banuprakash KG, Narayanaswamy TK and Bhaskar RN 2015. Estimation of genetic variability and correlation studies in mulberry Morus spp. Mysore J. Agric. Sci. 49(3): 516-522.

Burton GW and Devane EM 1953. Estimating heritability in tall fescue (Festuca arundinacea) from replicated clonal material. Agronomy Journal 45: 478-481.

Das BC and Swami KS 1965. Some observations on interspecific hybridization in mulberry. Indian J. Seric. 4: $1-8$.

Doss SG, Chakraborti SP, Roychowdhuri S, Das NK, Vijayan K, Ghosh PD, Rajan MV and Qadri SMH 2012. Variability, heritability and genetic advance in mulberry (Morus spp.) for growth and yield attributes. Agric. Sci. 3(2): 208-213.

Doss SG, Rahman MS, Debnath S, Ghosh MK, Sau H, Ghosh PL and Sarkar A 2006. Variability, heritability and genetic advance in nine germplasm lines of mulberry (Morus spp.). Indian Journal of Genetics 66: 169-170.

Goel AK, Ravindran S, Rao AA, Naik GV, Tikader A, Mukherjee P and Sekar S 1998. Variability in rooting parameters at juvenile stage in mulberry (Morus spp.) germplasm. Indian J. Seric. 37(2): 109-112.

Hanson CH, Robinson HF and Comstock RE 1956. Biometrical studies of yield in segregating population of Korea Lespedeza. Agron. J. 48: 267-282.

Johnson HW, Robinson HF and Comstock RE 1955. Estimates of genetic and environmental variability in soybeans. Agronomy Journal 47: 314-318.

Mallikarjunappa RS, Venkateshaiah HV, Rao MSE, Anantharaman MN and Bongale UD 2008. Genetic variability and correlation studies in mulberry germplasm. Indian J. Seric. 47(2): 226-229.

Masilamani S, Reddy AR, Sarkar A, Srinivas BT and Kamble CK 2000. Heritability and genetic advance of quantitative traits in mulberry (Morus spp.). Indian J. Seric. 39: 16-20.

Murthy KBC, Puttaraju HP and Hittalmani S 2010. Genetic variability and correlation studies in selected mulberry (Morus spp.) germplasm accessions. Electronic Journal of Plant Breeding 1(3): 351-355.

Quader MA, Qayyum MA, Sarkar AA, Rab MA and Ahmed SU 1992. Varietal response to NPK-fertilizers in combination with foliar spray of urea on leaf yield and quality of mulberry. Bull. Sericult. Res. 3: 54-66.

Rahman MS, Doss SG, Debnath S, Roychowdhuri S, Ghosh PL and Sarkar A 2006. Genetic variability and correlation studies of leaf characters in some mulberry (Morus spp.) germplasm accessions. Indian Journal of Genetics 66: 359-360.

Roy RK, Majumder RR, Sultana S, Hoque ME and Ali MS 2015. Genetic variability, correlation and path coefficient analysis for yield and yield components in transplant aman rice (Oryza sativa L.). Bangladesh J. Bot. 44(4): 529-535.

Saini P, Chauhan SS, Shabnam AA, Chand Lal and Negi N 2018. Genetic variability and trait association analysis for agro-morphological markers in mulberry genetic resources from Kashmir, India. Int. J. Curr. Microbiol. App. Sci. 7(4): 1799-1812.

Suresh K, Jalaja SK, Banerjee R and Trivedy K 2017. Genetic variability, correlation and path analysis in physiological and yield attributes in mulberry (Morus spp.). J. Crop Weed 13(1): 28-33.

Tikader A and Kamble CK 2008. Studies on variability of indigenous mulberry germplasm on growth and leaf yield. Pertanika J. Trop. Agric. Sci. 31: 163-170.

Tikader A and Kamble CK 2009. Developmet of core collection for perennial mulberry (Morus spp.) germplasm. Pertanika Tech. J. Sci. 17: 43-51.

Tikader A and Roy BN 1999. Genetic variability and character association in mulberry (Morus spp.) germplasm accessions. Indian J. For. 22: 26-29.

Tikader A, Thangavelu K and Rao AA 2004. Characterization and evaluation of mulberry (Morus spp.) germplasm. Indian J. Seric. 43(1): 106-110.

Vijayan K, Tikader A, Das KK, Chakraborti SP and Roy BN 1997. Correlation studies in mulberry (Morus spp.). Indian J. Genetics 57: 455-460.

Weber CR and Moorthy BR 1952. Heritable and non heritable relationships and variability of oil continent and agronomic characters in the $\mathrm{F}_{2}$ generations of soyabean crosses. Agron. J. 44: 202-209. 